\title{
Ruth Abbey
}

\section{Charles Taylor (1931-)}

Charles Taylor blev født den 5. november 1931 i Montreal, Quebec, i Canada. I 1952 opnåede han en bachelorgrad i historie med udmærkelse fra McGill University i Montreal. Han tog endnu en bachelorgrad i 1955 ved Balliol College i Oxford, denne gang i politik, filosofi og økonomi, og igen med udmærkelse. Han blev i 1960 og 1961 tildelt hhv. en kandidat- og en ph.d.-grad i filosofi efter at have været ansat ved All Souls College i Oxford. I 1961 vendte han tilbage til McGill University i Canada, hvor han blev ansat ved Department of Philosophy og Department of Political Science. I 1976 vendte han tilbage til Oxford for at overtage Chichele-professoratet i social og politisk teori, men vendte atter engang tilbage til Montreal i 1981 - den by, som han elsker, og som forbliver hans hjem.

Taylors hjemkomst udelukkede ham dog ikke fra en række ansættelser ved institutioner som Institute for Advanced Study i Princeton, Hebrew University i Jerusalem og New School of Social Research i New York. Han trak sig tilbage fra McGill university i 1998, men er fortsat professor emeritus ved Department of Philosophy samme sted. Fra 2002-2007 har han været medlem af lærerkollegiet ved Northwestern University i Evanston, Chicago, både som ansat ved Law School og ved Weinberg College of Arts and Sciences, og derudover fungerer han som Board of Trustees-professor.

Taylor har publiceret hyppigt $\mathrm{i}$ over fire årtier og har engageret sig i diskussioner om mange af de vigtigste filosofiske spørgsmål. Han har indtaget markante standpunkter inden for områder som ontologi, epistemologi, moralfilosofi, filosofisk antropologi, hermeneutik og sprogfilosofi, såvel som inden for social og politisk teori. Kendskab til blot nogle få detaljer i Taylors biografi kaster lys over nogle af hans vigtigste problemfelter og bidrag til filosofien. F.eks. lader det sig vanskeligt benægte, at det at bo i Quebec - en provins, der konstant diskuterer sin fortsatte rolle i den canadiske føderation - har 
påvirket Taylors arbejde som politisk filosof. Hans overvejelser over nationalisme, over demokratiets behov for inklusion og hans vigtige redegørelse for anerkendelsens politik har alle været direkte påvirkede af hans erfaring med at leve og være politisk aktiv i Quebec. I et mere bredspektret perspektiv har det at bo $i$ et land, som grænser op til verdens største og sandsynligvis stadigvæk mest selvsikre liberale demokrati også formet Taylors tanker om forskellige typer og opfattelser af liberalisme. De mange skæringspunkter mellem Taylors politiske erfaring og hans politiske filosofi er ikke mindst genstand for omfattende videnskabelige overvejelser i Mark Redheads bog Charles Taylor: Tbinking and Living Deep Diversity.

Taylors far var engelsktalende protestant, mens hans mor var fransktalende katolik, og opvæksten i denne tokulturelle, tosprogede familie har også vist sig at have haft betydning for udviklingen af hans tænkning, eftersom hensynet til sprog og kultur aldrig befinder sig langt fra essensen af de spørgsmål, han beskæftiger sig med, uanset emnet. Selv drager Taylor en forbindelse mellem sin filosofiske interesse for sprog og sin personlige baggrund, når han betænker, at

efter at have tilhørt en gennem flere generationer blandet familie, forekom det mig altid indlysende, at sproget er mere end et instrument; at ethvert sprog bærer sin egen form for humor, verdensopfattelse etc. Deraf min interesse for sprog og for den romantiske sprogfilosofi, som kritiserer Hobbes, Locke og Condillacs instrumentalistiske filosofi. (Taylor 1998: 109)

Det ville være vanskeligt at overvurdere den vægt, som Taylor tillægger sproget og kulturen i frembringelsen og videregivelsen af den menneskelige tilværelses betydning. Imidlertid er det et af de interessante og udfordrende karakteristika ved hans tænkning, at selvom han tillægger kulturen og sproget en stor identitetsskabende betydning, anerkender han ingen forestilling om, at identitet udelukkende er et artefakt af kultur eller sprog. Dette skyldes, at Taylor til noget sådant som en forestilling om den menneskelige natur tilslutter sig en overbevisning om, at der er visse kendetegn, som nødvendigvis følger med det at være menneske, og som overskrider tidsmæssige, geografiske, kulturelle og sproglige forskelle. Vi ser derfor en blanding af forskellige elementer $i$ hans tilnærmelse til en filosofisk antropologi: Nogle aspekter ved selvet kan udelukkende forstås under henvisning til en persons bredere kulturelle kontekst, mens andre udgør en integreret del af, hvad det vil sige at være menneske.

Blandt de kendetegn, som alle mennesker deler, er efter Taylors opfattelse følgende: Det at være sproglige dyr, det at være selvfortolkende dyr, det at 
have identiteter, som i dybtgående forstand konstitueres gennem dialog, det at have intentioner, der spiller en vigtig rolle i en persons opfattelse af, hvem vedkommende er, og endelig det at være situeret $i$, hvad Taylor kalder for et moralsk rum, hvilket vil sige at være stedfæstet inden for en moralsk struktur med en vis orientering mod det gode, og det at være en stærk bedømmer af værdier.

Begge disse aspekter af Taylors tilnærmelse til filosofisk antropologi - den stedsevarende og den kulturafhængige - er klart belyste i hans største arbejde indtil nu, Sources of the Self: The Making of the Modern Identity. I første del af Sources skitserer han de kendetegn, han opfatter som konstitutive for det menneskelige selv, mens han i del II-V bestemmer de særligt moderne aspekter ved selvet og eftersporer de måder, som disse har udviklet sig på. Denne opgave er ikke ligetil, fordi en af de ting, Taylor lægger vægt på, er det moderne selvs mangfoldighed: Forskellige tråde og kilder - sommetider komplementære og andre gange modstridende - har bidraget til skabelsen af den moderne identitet.

En af de vigtigste værdier, som Taylor forbinder med det moderne selv er en frigjort opfattelse af frihed. Frem for at opfatte sig selv som værende forbundet med en større kosmisk-moralsk orden, mener det moderne selv at kunne forstå og karakterisere sig selv rigtigt i fraværet af enhver forbindelse til en sådan omkringliggende virkelighed. Det frigjorte selv gør sin verden til et objekt og står heroverfor som et subjekt, hvis opgave det er at forstå og kontrollere verden (Taylor 1998: 188).

En andet vigtigt aspekt ved det moderne selv er indadvendthed. Det moderne selv opfatter sig som et væsen med indre dybder og anser det for en værdifuld forpligtelse at udforske, opnå kendskab til og måske at udtrykke disse indre dybder (Taylor 1989: 178). For det tredje har det moderne selv en stærk fornemmelse af sin egen individualitet eller unikke karakter, og bestræber sig på at leve på en måde, som er tro imod denne individualitet. Ifølge denne 'autenticitetens etik', som Taylor kalder det, må enhver opdage sin egen originale måde at være til på, anerkende den som et oprigtigt eller tro udtryk for, hvem han eller hun er, og tage den i brug samt tage ansvar for den.

Det fjerde aspekt ved det moderne selv er forestillingen om naturen som kilde. Hermed mener Taylor, at det moderne selv nærer en opfattelse af, at vekselvirkning med den naturlige verden kan være en kilde til moralsk fornyelse, og at en sådan kontakt sætter selvet i stand til at lytte til naturens stemme i det indre. Kontakten med naturen opfattes som noget overordentligt værdifuldt. Endelig gennemtrænges det moderne selv af en etos, som Taylor kalder for 'anerkendelsen af hverdagslivet'. Dette drejer sig om den forestilling, at det, som sker i arbejdets og familiens sfærer, leverer et substantielt bidrag til ens opfattelse af livets mening og værdi. 
Det er et sammensat billede af det moderne selv, som Taylor eftersporer i Sources. Det er værd at lægge mærke til, at hans fokus i konstruktionen af det moderne selvs historie i overvældende grad er rettet mod det kulturelle område. Inden for dette kulturfelt hviler accenten tungt på kanoniske filosofiske værker. Selv når han ser ud over filosofien mod andre kulturelle produkter, er Taylors interesse tilbøjelig til at dvæle ved skrevne tekster, selvom de måder, hvorpå forskellige typer af kulturel aktivitet, såsom musik og de visuelle kunstarter, har bidraget til den moderne identitet, også tillægges en vis betydning. På trods af, at han ikke benægter deres indflydelse, udviser Taylor dog samlet set minimal opmærksomhed over for den rolle, som økonomiske aktiviteter og institutioner, forandringer i produktionsmønstre, videnskab og teknologi eller regerings- og retssystemer har spillet i skabelsen af den moderne identitet.

Taylors seneste bog, Modern Social Imaginaries beskæftiger sig fortsat med den bekymring for det særligt etiske eller normative træk ved den moderne eksistens, der kommer til udtryk i Sources, selvom der her lægges mindre vægt på det at filosofere over selvet og mere vægt på at artikulere de formodninger, forudsætninger og overbevisninger, som der er behov for $\mathrm{i}$ forbindelse med vurderingen af den moderne vestlige opfattelse af samfund, økonomi og politik. Med termen 'social forestilling' henviser Taylor til den upræcise, generelle og ofte indforståede fornemmelse, som folk har af, hvordan samfund fungerer og hvad der holder dem sammen. Som han formulerer det, så beskriver udtrykket

den måde, hvorpå folk forestiller sig deres sociale tilværelse, hvordan de passer sammen med andre, hvordan det forholder sig mellem dem og deres kolleger, de forventninger, man normalt møder, og de dybere normative idéer og forestillingsbilleder, som ligger til grund for disse forventninger. (Taylor 2004: 23)

En stor del af Taylors interesse $i$ dette projekt ligger $i$ at undersøge, hvordan moderne individer kan forstå sig selv, deres samfund og den naturlige verden i en ren og skær sekulær forstand, uden nogen fornøden reference til hverken det guddommelige eller til en anden form for transcendent virkelighed. Imidlertid mener han også, at vi ved at kortlægge den moderne sociale forestillingsform, sådan som denne har udviklet sig i Vesten, vil opnå bedre forudsætninger for at anerkende de forskelligartede måder, hvorpå forskellige kulturer har moderniseret sig selv og forsat gør det. Som dette antyder, fører der ingen direkte vej til destinationen 'det moderne samfund': Forskellige kulturer kan indoptage hovedbestanddele fra moderniteten på forskellige måder, således at moderne former for kommunikation, information, teknologi, industrialisering, statsdannelse og økonomisk organisering kan få forskellige 
betydninger inden for forskellige kulturer. Som en konsekvens kan forskellige kulturer derfor have forskellige sociale forestillingsformer, når det kommer til modernitet.

Blandingen af ontologiske og historiske faktorer i Taylors indfaldsvinkel til filosofisk antropologi giver ham ikke blot en særpræget filosofisk antropologi, men leverer ham også et alternativ til den blotte accept og anerkendelse af en given kulturs overbevisninger, værdier og selvforståelse. Ved at fastholde, at der knytter sig visse ontologiske sandheder til det at være menneske, er Taylor i stand til at stille skarpt på og kritisere en hvilken som helst kulturs selvforståelse, inklusive sin egen. På denne måde kan han tydeliggøre de kulturelle kræfters betydning for udformningen af selvfortolkninger, overbevisninger og etikker uden at henfalde til kulturel relativisme og til nødvendigheden af uden forbehold at tilslutte sig alle dimensionerne i en kulturs selvopfattelse. Et godt eksempel på Taylors evne til at forholde sig kritisk distanceret $\mathrm{i}$ forhold til stærke kulturelle overbevisninger findes $i$ hans velkendte kritik af atomismen.

Atomisme er et andet udtryk for individualisme, men henviser særligt til individets ontologiske forrang. Taylor forbinder atomismen med opkomsten af social kontrakttænkning fra det 17. århundrede og frem - især de engelske filosoffer Thomas Hobbes og John Lockes værker. I dag er den atomistiske synsvinkel dog allestedsnærværende i vestlige samfund; faktisk har den udviklet et så fast greb omkring moderne vestlige sociale og politiske forestillingsformer, at den tages for givet som et naturligt standpunkt. Som Taylor konstaterer, så

har atomistiske synspunkter altid forekommet at være tættere på almindelig sund fornuft, mere umiddelbart tilgængelige [...] Det er som om, at vi uden en særlig eftertænksom indsats har tilbøjelighed til at falde tilbage til en atomistisk-instrumentalistisk måde at opfatte tingene på. Dette synes at dominere vores ureflekterede oplevelse af samfundet. (Taylor 1998: 196)

Taylors udnævnelse ovenfor af Hobbes og Locke som tænkere, der tilslutter sig en instrumentalistisk forestilling om sproget, er ikke tilfældig, eftersom han mener, at en ontologi om det menneskelige og en teori om sproget er to lag inden for en filosofisk position, der sandsynligvis er nært beslægtede. Som det vil fremgå, er dette i høj grad tilfældet hos Taylor.

I direkte modstrid med atomistisk sund fornuft insisterer Taylor på, at selvet altid er socialt situeret, og at den enkelte nødvendigvis peger ud over sig selv i retning af sine sociale relationer. Fællesskabet har efter hans opfattelse en ontologisk forrang i forhold til den enkelte på grund af den måde, hvorpå irreduktible kollektive kræfter som kultur og sprog former og informerer en- 
keltindivider. Derfor argumenterer han for, at eftersom visse goder for selvet og sågar forestillinger om det udelukkende er tilgængelige for enkeltpersoner i kraft af den kultur, som disse tilhører, så indtager det at tilhøre et fællesskab eller et samfund en førerposition i forklaringen af sociale og politiske normer, værdier og praksis. Hobbes og Locke må logisk set tendere en instrumentalistisk opfattelse af sproget, fordi de som fortalere for en atomistisk ontologi ikke, med risiko for at modsige sig selv, kan medgive, at en kollektiv kraft som sproget skulle være konstitutiv for personlig identitet. For dem er sproget derfor et redskab i de individuelle formåls tjeneste snarere end en kraft, som former enkeltpersoner og deres interesser.

Frem for at afvise samtlige forestillinger om individualisme, har Taylor imidlertid forsøgt at forklare dem ved at udpege deres bredere kulturelle kilder. Han hævder således, at selv "det frie individuelle eller autonome handlingssubjekt" - som i den grad er dybt manifesteret i den moderne vestlige kulturs opfattelse af sund fornuft - "kan udelukkende opnå og bevare sin identitet inden for en bestemt form for kultur." Et sådant individ "er kun, hvad han er, i kraft af hele det samfund og den civilisation, som skabte ham og giver næring til ham." (Taylor 1985 (2): 205-206). I denne sammenhæng har Taylors indsats som en fortolker af G.W.F. Hegel (Taylor 1975; 1979) været vigtig, fordi hans omhyggelige studier af Hegels filosofi har hjulpet ham til at identificere og kritisere udbredelsen af atomistiske synspunkter i vestlig kultur $i$ almindelighed og inden for sociale videnskaber i særdeleshed.

Et andet eksempel på, hvordan de ontologiske aspekter ved Taylors tænkning gør ham i stand til at kritisere doktriner og overbevisninger, som er blevet fremtrædende i udformningen af moderne individers og samfunds selvforståelse, findes i hans kritik af den figurative epistemologi. Dette er et begreb om viden, som er baseret på den idé, at mennesker skaber indre, mentale billeder af eller forestillinger om den omkringliggende verden. Jo bedre det indre passer til det ydre, desto mere pålidelig eller sand er erfaringen. Ud fra dette synspunkt"skal viden opfattes som en uafhængig virkeligheds korrekte repræsentation." (Taylor 1995: 3). En pålidelig metode - en troværdig fremgangsmåde for tilvejebringelse af sandheden - er på sin side den bedste garanti for, at det indre og det ydre passer sammen.

Det figurative begreb om viden forudsætter og fremmer på én gang, hvad Taylor kalder for en 'frigørende' holdning fra det vidende subjekts side, og er derfor nært forbundet med det moderne selvs valorisering af frigjort frihed, som blev diskuteret ovenfor. Fordi viden opfattes som viden om en uafhængig virkelighed, forudsætter den figurative epistemologis frigjorte tilgang til tingene, at subjektet på visse områder adskilles fra verden omkring sig, og at denne verden transformeres til et undersøgelsesobjekt (eller til en serie af 
adskilte undersøgelsesobjekter). Med henblik på at udvikle viden, der er så pålidelig som mulig, gøres der ansatser til at minimere enhver tænkelig forstyrrelse af subjektiviteten $i$ undersøgelsesprocessen. Taylor indrømmer, at de moderne naturvidenskabers landvindinger står i dyb gæld til dette figurative begreb om viden, men det begynder at bekymre ham, når dette særlige begreb om, hvad det er at vide, blandes sammen med menneskelig viden som sådan; når det ender med at blive opfattet som det dominerende - eller endda det eneste - begreb om epistemologi.

Med henblik på at bekæmpe den figurative metodes overherredømme og genindsætte denne på sin rette plads som én måde at beskrive én form for menneskelig undersøgelse på, skitserer Taylor en idé om det, han kalder for 'engageret, legemliggjort viden'. Fordi den figurative opfattelse af viden underdriver og forsøger at overskride den engagerede legemliggjorte videns rolle i vidensudviklingen, bliver det nødvendigt at oprette påmindelser om signifikansen af både kroppen og den imperative betydning af praktisk omgang med verden for den menneskelige forståelse. Inspireret af Hegel, Martin Heidegger, Maurice Merleau-Ponty og Ludwig Wittgensteins værker, henleder Taylor opmærksomheden på den kendsgerning, at vi mennesker i vore almindelige måder at være i verden på er skabninger med kroppe, som befinder sig i en verden, hvor vi bliver nødt til at handle og imødekomme praktiske krav. Dette billede af en engageret, legemliggjort virksomhed udfordrer ikke blot tendensen til at bagatellisere kroppens indvirkning på almindelige vidensformer, men også selve muligheden for en adskillelse af indre/ydre, som karakteriserer den figurative tilnærmelse til viden. Den slags know-how, som kommer til udtryk i den dagligdags omgang med verden, kan ikke defineres som noget, der alene findes enten i mit hoved eller i min krop. Den manifesterer sig selv i en måde at virke på $\mathrm{i}$ og med verden, således at enhver tanke om at adskille selvet fra verden bliver anstrengt og kunstig.

Ifølge Taylors opfattelse er vores position som engagerede, legemliggjorte subjekter for viden vigtigere end - og faktisk forudsætningen for - figurativ viden. Når først denne vidensforms grundlæggende betydning bliver tilgodeset, kan den figurative tilnærmelse til viden erkendes som værende rundet af denne mere fundamentale måde at være i og kende verden på. Den begrænsede, frigjorte tilnærmelse til epistemologien muliggøres kun under inddragelse af de bredere forudsætninger for den dagligdags væren i og omgang med verden.

Et andet af de bemærkelsesværdige aspekter ved Taylors værk er, at han $\mathrm{i}$ høj grad trækker på tænkere fra det kontinentale Europa - Heidegger, Merleau-Ponty, Jean Jacques Rousseau, Johann Gottfried Herder og Wilhelm von Humboldt for at nævne nogle få. På trods af sit energiske engagement i og gældsforhold til europæiske traditioner og måder at tænke på, skriver Taylor 
dog typisk i et læservenligt sprog. Selv i forbindelse med diskussionen af de mest komplekse epistemologiske eller moralteoretiske spørgsmål er hans stil klar og indimellem ligefrem uformel. Og akkurat ligesom han rækker ud efter ikke-engelske - og i stigende grad ikke-vestlige - kilder for at berige og udvide sin tænkning, bliver Taylors eget værk fortsat oversat til andre sprog and engelsk. Hans bøger om Hegel er tilgængelige for læsere af kinesisk, fransk, tysk, italiensk, japansk, persisk, spansk og svensk. Sources of the Self er blevet oversat til kinesisk, fransk, tysk, italiensk og spansk, mens Taylors portrættering af anerkendelsens politik er blevet gjort tilgængelig for læsere af hollandsk, fransk, tysk, italiensk, japansk, spansk, svensk og tyrkisk.

Oversat fra engelsk af Birgitte Eskildsen

\section{Bibliografi}

Taylor, Charles (1964): The Explanation of Behaviour, London: Routledge \& Kegan Paul. -(1970): The Pattern of Politics, Toronto: McClelland and Stuart.

-(1975): Hegel, Cambridge: Cambridge University Press.

-(1975): Erklärung und Interpretation in den Wissenschaften vom Menschen, Frankfurt: Suhrkamp Verlag. -(1979): Hegel and Modern Society, Cambridge: Cambridge University Press. -(1983): Social Theory As Practice, Delhi, NY: Oxford University Press.

-(1985): Human Agency and Language: Pbilosophical Papers 1, Cambridge: Cambridge University Press.

-(1985): Philosopby and the Human Sciences: Philosophical Papers 2, Cambridge: Cambridge University Press.

-(1988): Negative Freibeit? Zur Kritile des neuzeittichen Individualismus, Frankfurt: Suhrkamp Verlag.

-(1989): Sources of the Self: The Making of the Modern Identity, Cambridge, Mass.: Cambridge University Press.

-(1991): The Malaise of Modernity, Ontario: House of Anansi Press.

Genoptrykt som

-(1992): The Ethics of Authenticity, Cambridge, Mass.: Cambridge University Press.

Dansk oversættelse i

-(2002): Modernitetens Ubehag - Autenticitetens Etik, Århus: Forlaget Philosophia.

-(1992): Multiculturalism and 'The Politics of Recognition', Amy Gutmann (red.), Princeton NJ:

Princeton University Press.

-(1993): Reconciling the Solitudes: Essays in Canadian Federalism and Nationalism, Guy Laforest (red.), Montreal og Kingston: McGill-Queen’s University Press. 
-(1995): Philosophical Arguments, Cambridge, Mass.: Cambridge University Press.

-(1995): Identitet, Frihet och Gemenskap: Politisk-Filosofiska Texter, H. Grimen (red.), Göteborg:

Daidalos.

-(1996): De politieke Cultur van de Moderniteit, The Hague: Martinus Nijhoff.

-(1997): La liberté des modernes. Essais choisis, traduits et présenté par Philippe de Lara, Paris: PUF. -(1999) : A Catholic Modernity? James L. Heft (red.), Oxford, NY: Oxford University Press.

-(2002): Varieties of Religion Today: William James Revisited, Cambridge, Mass.: Cambridge

University Press.

-(2002): Wieviel Gemeinschaft braucht die Demokratie? Aufsätze zur politische Philosophie, Frank-

furt: Suhrkamp Verlag.

-(2004): Modern Social Imaginaries, Dilip Gaonkar, Jane Kramer, Benjamin Lee og Michael

Warner (red.), Durham, NC: Duke University Press.

\section{Andre relevante arbejder:}

Taylor, Charles (1994, sm. m. Vitit Muntarbhorn): Roads to Democracy: Human Rights and Democratic Development in Thailand, Bangkok og Montreal: International Centre for Human Rights and Democratic Development.

Taylor, Charles (1998): "From Philosophical Anthropology to the Politics of Recognition: An Interview with Philippe de Lara" i Thesis Eleven vol. 52, 103-112.

\section{Videre lasning:}

Abbey, Ruth (2000): Charles Taylor, Princeton, NJ: Princeton University Press.

Abbey, Ruth (red., 2004): Contemporary Philosophy in Focus: Charles Taylor, Cambridge, NY: Cambridge University Press.

Redhead, Mark (2002): Charles Taylor: Thinking and Living Deep Diversity, Lanham, MD: Rowman \& Littlefield pub.

Smith, Nicholas H. (2002): Charles Taylor: Meaning, Morals and Modernity, Cambridge: Polity Press.

Spence, Keith (2004): Charles Taylor: Modernity, Freedom and Community, Cardiff, Whales: Paul \& Co. Pub. Consortium.

Tully, James (red., 1994): Philosophy in an Age of Pluralism: The Philosophy of Charles Taylor in Question, Cambridge: Cambridge University Press. 